\title{
Correction to: Low birthweight, prematurity, and intrauterine growth restriction: results from the baseline data of the first indigenous birth cohort in Brazil (Guarani Birth Cohort)
}

\author{
Carla Tatiana Garcia Barreto ${ }^{1,2^{*}}$, Felipe Guimarães Tavares ${ }^{3}$, Mariza Theme-Filha ${ }^{2}$, Yasmin Nascimento Farias²,
} Lídia de Nazaré Pantoja ${ }^{2}$ and Andrey Moreira Cardoso ${ }^{2}$

\section{Correction to: BMC Pregnancy Childbirth 20, 748 (2020)} https://doi.org/10.1186/s12884-020-03396-8

An error occurred during the publication of the original article [1] which led to the text being incorrectly converted into Portuguese.

The Publisher apologizes for this error and any confusion caused.

The original article has been corrected.

\section{Author details}

'Universidade do Estado do Rio de Janeiro (UERJ), Av. Marechal Rondon, 381. São Francisco Xavier, Rio de Janeiro, RJ CEP: 20950-000, Brasil. ${ }^{2}$ Escola Nacional de Saúde Pública, Fundação Oswaldo Cruz, Rio de Janeiro, RJ, Brasil. ${ }^{3}$ Escola de Enfermagem Aurora de Afonso Costa. Faculdade de Enfermagem, Universidade Federal Fluminense, Niterói, RJ, Brasil.

Published online: 30 December 2020

\section{Reference}

1. Barreto, et al. Low birthweight, prematurity, and intrauterine growth

restriction: results from the baseline data of the first indigenous birth cohort

in Brazil (Guarani Birth Cohort). BMC Pregnancy Childbirth. 2020;20:748.

https://doi.org/10.1186/s12884-020-03396-8.

The original article can be found online at https://doi.org/10.1186/s12884020-03396-8

* Correspondence: carlatgbarreto@gmail.com

'Universidade do Estado do Rio de Janeiro (UERJ), Av. Marechal Rondon, 381. São Francisco Xavier, Rio de Janeiro, RJ CEP: 20950-000, Brasil

Escola Nacional de Saúde Pública, Fundação Oswaldo Cruz, Rio de Janeiro, RJ, Brasil

Full list of author information is available at the end of the article

C C The Author(s). 2020 Open Access This article is licensed under a Creative Commons Attribution 4.0 International License, which permits use, sharing, adaptation, distribution and reproduction in any medium or format, as long as you give appropriate credit to the original author(s) and the source, provide a link to the Creative Commons licence, and indicate if changes were made. The images or other third party material in this article are included in the article's Creative Commons licence, unless indicated otherwise in a credit line to the material. If material is not included in the article's Creative Commons licence and your intended use is not permitted by statutory regulation or exceeds the permitted use, you will need to obtain permission directly from the copyright holder. To view a copy of this licence, visit http://creativecommons.org/licenses/by/4.0/ The Creative Commons Public Domain Dedication waiver (http://creativecommons.org/publicdomain/zero/1.0/) applies to the data made available in this article, unless otherwise stated in a credit line to the data. 